\title{
PERUMUSAN STRATEGI BISNIS PT XYZ
}

\section{FORMULATION OF BUSINESS STRATEGY PT XYZ}

\author{
Roy Hutahaean*1, Idqan Fahmi*), dan Ahmad Mukhlis Yusuf**) \\ *) Sekolah Bisnis, Institut Pertanian Bogor \\ Jl. Raya Pajajaran, Bogor 16151 \\ **) Magister Manajemen BINUS University \\ Jl. Syahdan No. 9, Jakarta 11480
}

\begin{abstract}
The purpose of this study is to formulate business strategy of XYZ Company. This study used 4 analysis tool Matrixes i.e. IFE (Internal Factor Evaluation) and EFE (External Factor Evaluation), SWOT (Strength, Weaknesses, Opportunities, and Threat), and QPSM (Quantitative Strategic Planning Matrix). The primary and secondary data were used for this study. The IFE and EFE analysis showed weighted values of 2.52; 3.31 in quadrant II, indicating that this company is still in growth and development phase while, through the SWOT analysis, 5 alternative strategies could be concluded i.e. (1) collaboration with government to provide special fleet as domestic transportation to support national shipping industry; (2) collaboration not only with Head company but also with the other multi-stakeholders; (3) Capacity building regarding development of national shipping industry to XYZ employees; (4) establishment of agreement among multi-stakeholders against corruptions, collusion and nepotism; (5) development of a good working mechanism in accordance with the structural organization to increase working efficiency. Lastly, based on QPSM analysis, the main priority in business strategy of XYZ Co. is the capacity building for all of its employees.
\end{abstract}

Keywords: business strategy, IFE,EFE, SWOT Matrix, QSPM

\begin{abstract}
Abstrak: Penelitian ini bertujuan memformulasikan strategi bisnis PT. XYZ melalui pendekatan analisis deskriptif. Alat alat analisis yang digunakan, yaitu matrix IFE (Internal factor Evaluation) dan EFE (External Factor Evaluation), SWOT (Strength, Weaknesses, Opportunities, and Threat) dan QSPM (Quantitative Strategic Planning Matrix). Data yang digunakan adalah data primer dan sekunder. Berdasarkan hasil IFE dan EFE diperoleh nilai tertimbang masing masing sebesar $(2,523 ; 3,310)$ sehingga posisi perusahaan dalam matriks IE berada di kuadran II, yaitu tumbuh dan kembangkan. Berdasarkan hasil analisis SWOT diperoleh lima alternatif strategi (1) bekerja sama dengan pemerintah dalam menyiapkan armada khusus untuk pengangkutan dalam negeri sehingga mendukung industri pelayaran nasional; (2) bekerja sama dengan pihak lain diluar Perusahaan induk; (3) peningkatan kapasitas tentang pengembangan industri pelayaran nasional kepada staff; (4) membangun kesepakatan dengan pihak-pihak terkait untuk memberantas korupsi, kolusi dan nepotisme (5) membangun mekanisme kerja yang baik sesuai dengan struktur organisasi sehingga dapat meningkatkan efisiensi kerja. Berdasarkan analisis QSPM prioritas utama dalam perumusan strategi bisnis PT.XYZ adalah peningkatan kapasitas seluruh staff.
\end{abstract}

Kata kunci: perumusan strategi, IFE, EFE, SWOT Matrix, QSPM

\footnotetext{
${ }^{1}$ Alamat Korespondensi:

Email: hutahhaean_roy@yahoo.co.id
} 


\section{PENDAHULUAN}

Menurut Lembaga Ilmu Pengetahuan Indonesia (LIPI), Indonesia merupakan negara kepulauan terbesar di dunia, memiliki wilayah seluas 7,7 juta $\mathrm{km}^{2}$, dengan luas lautan 2/3 wilayah Indonesia, dan garis pantai terpanjang ke empat di dunia sepanjang $95.181 \mathrm{~km}$. Transportasi laut (kapal) merupakan sarana transportasi utama guna menjangkau dan menghubungkan pulaupulau di wilayah nusantara sehingga menciptakan konektifitas antar pulau di Indonesia.

permintaan akan transportasi laut akan sangat memengaruhi perkembangan perekonomian dan perindustrian suatu negara (Gao dan Yoshida, 2013) karena bernilai paling ekonomis dan dapat mengangkut jumlah muatan yang besar (Lagoudis et al. 2004). Tanpa pengangkutan (ekspor dan impor) maka perkembangan perekonomian tidak akan dapat berjalan lancar. Menurut BPS (2014) total ekspor batu bara sampai dengan akhir tahun 2014 mencapai 408 juta ton tentunya hal tersebut merupakan sebuah peluang yang besar bagi perkembangan industri pelayaran Indonesia. Pada kondisi pasar yang sangat kompetitif perusahaan harus memiliki pemahaman yang menyeluruh mengenai kondisi internal dan external perusahaanya untuk menentukan suatu strategi yang tepat (Xia Chan, 2011). Komaryatin (2007) dan Kurniawati dan Sari (2009) menyebutkan bahwa setiap perusahaan seharusnya dapat melihat jauh kedepan dalam mengembangkan strategi kedepanya untuk mengantisipasi kondisi kondisi persaingan yang semakin ketat.

PT.XYZ didirikan pada tahun 2005 yang merupakan anak perusahaan dari perusahaan induk di Indonesia. Sesuai dengan Misi awal XYZ merupakan perusahaan pelayaran yang mempunyai tugas utama adalah membidangi tentang shipment kapal (pemasok kapal) untuk impor gandum pada perusahaan induk, yang seluruhnya diimpor dari beberapa negara seperti. Australia, Canada, Rusia, dan juga India. Saat ini PT.XYZ mengoperasikan beberapa kapal curah yang berbobot mati (DWT) berkisar 50.000 sampai 70.000 MT. Kapal curah tersebut memang didesain khusus untuk pengangkutan gandum dan bahan-bahan curah lainya seperti bahan-bahan tambang (batu bara, biji besi, dll). PT.XYZ sudah beroperasi hampir 10 tahun akan tetapi PT.XYZ dalam mengoperasikan kapalnya masih sangat bergantung terhadap perusahaan induk (single market) dan sampai saat ini mayoritas kapal kapal PT.XYZ hanya digunakan untuk pengangkutan impor gandum dari luar negeri saja. Dengan demikian, beberapa armada PT.XYZ harus menuggu beberapa waktu yang lama (idle) dikarenakan tergantung dari permintaan/pembelian bahan baku dari perusahaan induk, perencanaan yang kurang matang dari perusahaan induk berdampak pada banyaknya kapal yang harus menunggu pada pelabuhan bongkar (dermaga khusus) dikarenakan pembelian secara besar besaran pada rentang waktu tertentu.

Kondisi tersebut tentunya berdampak pada performance PT.XYZ dikarenakan biaya operasional kapal yang tinggi untuk kapal idle. Kondisi tersebut menunjukan bahwa penting dilakukan penelitian mengenai faktor faktor apa yang dapat memengaruhi PT.XYZ untuk dapat mengembangkan usahanya pada jasa angkutan transportasi laut di Indonesia yang memiliki prospek/ potensi untuk dikembangkan. PT.XYZ harus dapat mengidentifikasikan faktor-faktor strategis apa saja yang memengaruhi lingkungan internal dan eksternal pengembangan usaha PT.XYZ di bidang pelayaran, Strategi bisnis apa yang dapat dikembangkan oleh PT.XYZ dalam mengembangkan usahanya di bidang pelayaran, strategi prioritas apa saja yang dapat diterapkan oleh PT.XYZ dalam upaya pengembangan usahanya di bidang pelayaran.

Penelitian penelitian yang terkait dengan perumusan strategi bisnis pada perusahaan pelayaran dilakukan oleh Hernowo (2000) melakukan penelitian tentang Perumusan strategi bisnis PT. Karana Line dimana terjadinya persaingan yang sangat ketat dalam bisnis pelayaran sehingga perusahaan perlu memformulasikan alternatif alternatif strategi yang diperlukan dalam mengantisipasi persaingan bisnis perusahaan pelayaran, yaitu melalui mengoptimalakan fungsi para agen diluar negeri sebagai marketer untuk memperluas jaringan perusahaan, mengoptimalkan fungsi chartering dalam mencari muatan muatan alternatif dan memberikan kemudahan bagi para customer tetap. Sheehan (2012) mengemukan bahwa perusahaan yang gagal dalam mengidentifikasi, mengantisipasi, dan mengelola risiko perusahaanya maka akan menimbulkan kegagalan pada perusahaanya. Disamping itu, Ziyi dan Shigeru (2013) juga melakukan penelitian tentang bagaimana perusahaan pelayaran menformulasikan alternatif strategi agar dapat bersaing pada industri pelayaran dikarenakan adanya kompetisi yang sangat ketat pada industri pelayaran, dalam penelitian tersebut diformulasikan tujuh alternatif strategi, yaitu peningkatan pendapatan, penurunan biaya operasional, 
peningkatan kepuasan konsumen, memperluas jaringan perusahaan dengan pelanggan baru, penerapan IT, mengevaluasi proses internal perusahaan dan peningkatan kepuasan para karyawan

Penelitian ini bertujuan menganalisis kondisi lingkungan internal dan eksternal yang memengaruhi pegembangan bisnis PT.XYZ, memformulasikan strategi bisnis yang dapat diterapkan untuk mengembangkan perusahaan di bidang pelayaran, menentukan prioritas strategi yang tepat dan yang dapat diterapkan oleh PT.XYZ dalam mengembangkan usahanya.

Adapun ruang lingkup dalam penelitian ini adalah menformulasikan suatu strategi yang tepat bagi PT.XYZ, mengidentifkasikan faktor-faktor internal dan eksternal dari perkembangan industri pelayaran di Indonesia sehingga penyusunan strategi mampu mengetahui kekuatan dan kelemahan serta peluang dan ancaman dari perkebangan industri pelayaran di Indonesia. Strategi yang dihasilakan ditujukan kepada PT.XYZ dan penerapanya diserahkan kepada perusahaan.

\section{METODE PENELITIAN}

Sumber data dalam penelitian ini terdiri dari data primer dan data sekunder. Data primer diperoleh dari hasil pengisian kuesioner serta dibantu dengan wawancara (indepth interview). Teknik pengambilan contoh dilakukan dengan non-probability sampling dan responden ditentukan dengan cara sengaja (purposive sampling). Hal ini dilakukan dengan pertimbangan bahwa responden yang dipilih memiliki pengetahuan, kemampuan, pengalaman, dan pemahaman yang relevan dibidangnya, seperti para manager, senior manajer dan general manajer yang ada di PT.XZY. Total jumlah responden ada 5 orang yang terdiri dari 4 responden internal perusahaan dan satu orang dari responden luar perusahaan. Data sekunder diperoleh dari studi literatur, biro pusat statistik, kementrian perhubungan, laporan perusahaan dan data-data publikasi lainya yang berhubungan dengan penelitian. Rincian jenis data yang dibutuhkan oleh penulis dapat dilihat pada Tabel 1.

Penelitian ini menggunakan analisis deskriptif dalam bentuk studi kasus pada PT.XYZ. Metode penelitian menggunakan pendekatan kualitatif dan kuantitaif. Pendekatan kualitatif menggunakan metode deskriptif dimana analisis deskriptif bertujuan mengidentifikasikan faktor internal dan eksternal dalam rangka merumuskan alternative strategi PT.XYZ analisis deskriptif dilakukan dengan pengamatan langsung, wawancara (indepth interview) dan studi literatur. Pendekatan kuantitatif dilakukan dengan pengisian kuesioner dipandu dengan wawancara terstruktur, kemudian hasil kuesioner dibobot dan dinilai.

Penelitian ini juga menggunakan analisis kuantitatif dan kualitatif dengan menggunakan pendekatan konsepkonsep manajemen strategis. Data dan informasi yang dihimpun melalui kuesioner kemudian ditabulasi secara silang untuk memudahkan proses pengolahan. Setelah itu data di analisis secara kualitatif untuk menentukan setrategiyang tepat. Analisis faktor internal dan eksternal dilakukan untuk mengetahui kondisi terkini dari PT.XYZ, kemudian dilakukan analisis SWOT. SWOT adalah singkatan dari lingkungan internal Strength dan Weakneses serta lingkungan eksternal Oppurtunities dan Threats yang dikaji dari masyarakat sebagai dasar dari penyusunan strategi untuk mencapai tujuan dan sasaran dalam bidang isu isu kunci (Kaufman dan Jacobs, 1996). untuk menyusun alternatif strateginya, kemudian untuk menentukan prioritas straegi digunakan matriks QSPM (Quantitative Strategic Planning Matrix). Analisis deskriptif merupakan analisis yang bertujuan memberikan gambaran tentang bagaimana kondisi terkini mengenai industri pelayaran di Indonesia. Kerangka pemikiran penelitian dapat dilihat pada Gambar 1.

\section{HASIL}

\section{Analisis Lingkungan Internal}

Kekuatan utama dari PT.XYZ adalah didukung oleh perusahaan induk yang besar dengan bobot 0,153. Dengan didukung oleh perusahaan induk yang besar dan memiliki brand image yang kuat secara tidak langsung maka perusahaan akan dapat dengan mudah memasuki pasar industri pelayaran lainya. Dengan brand image yang baik dari perusahaan induk maka secara langsung dapat memengaruhi konsumen untuk menggunakan jasa anak perusahaan dikarenakan atas kualitas servis yang sudah terbukti (Cifci dan Kocak, 2012). Meskipun memiliki kemampuan untuk melakukan inovasi, perusahaan cenderung melakukan 
kesalahan dengan tidak mengambil kesempatan yang ada sehingga perencanaan strategi yang sudah dibuat mengalami keterlambatan dalam pelaksanaanya (Powel, 2004). Kekuatan kedua adalah memiliki perjanjian dengan shipper/pihak muatan untuk mengangkut muatan gandum dalam jangka waktu tak terbatas dengan bobot 0,144 . Kekuatan ketiga adalah memiliki armada pengangkutan kapal curah yang sudah bersertifikasi internasional dengan bobot 0,109. PT.XYZ yang sudah menggunakan ISM code sebagai alat bantu untuk mencapai tingkat keselamatan yang sesuai dengan standar keselamatan internasional dalam mengoperasikan kapal menjadi kekuatan keempat dengan bobot 0,093 .

Tabel 1. Jenis dan sumber data yang diperlukan

\begin{tabular}{lll}
\hline \multicolumn{1}{c}{ Jenis data } & \multicolumn{1}{c}{ Teknik pengambilan } & \multicolumn{1}{c}{ Sumber data } \\
\hline $\begin{array}{l}\text { Data Primer } \\
\begin{array}{l}\text { Identifikasi Faktor eksternal dan } \\
\text { internal perusahaan }\end{array}\end{array}$ & $\begin{array}{l}\text { Kuesioner, wawancara (indepth } \\
\text { interview) } \\
\begin{array}{l}\text { Gambaran Lingkungan eksternal } \\
\text { perusahaan }\end{array}\end{array}$ & $\begin{array}{l}\text { Internal Perusahaan (Assisten Manager } \\
\text { s/d General Manajer ) }\end{array}$ \\
$\begin{array}{l}\text { Internal perusahaan \& eksternal } \\
\text { (professional) dan anggota INSA }\end{array}$ \\
$\begin{array}{l}\text { Visi dan Misi tujuan perusahaa } \\
\text { Profil perusahaan/ Struktur Organisasi } \\
\text { Kebijakan pemerintah }\end{array}$ & Review Data sekunder \\
Data pendukung lainya & & Data Laporan tahunan perusahaan \\
\hline
\end{tabular}

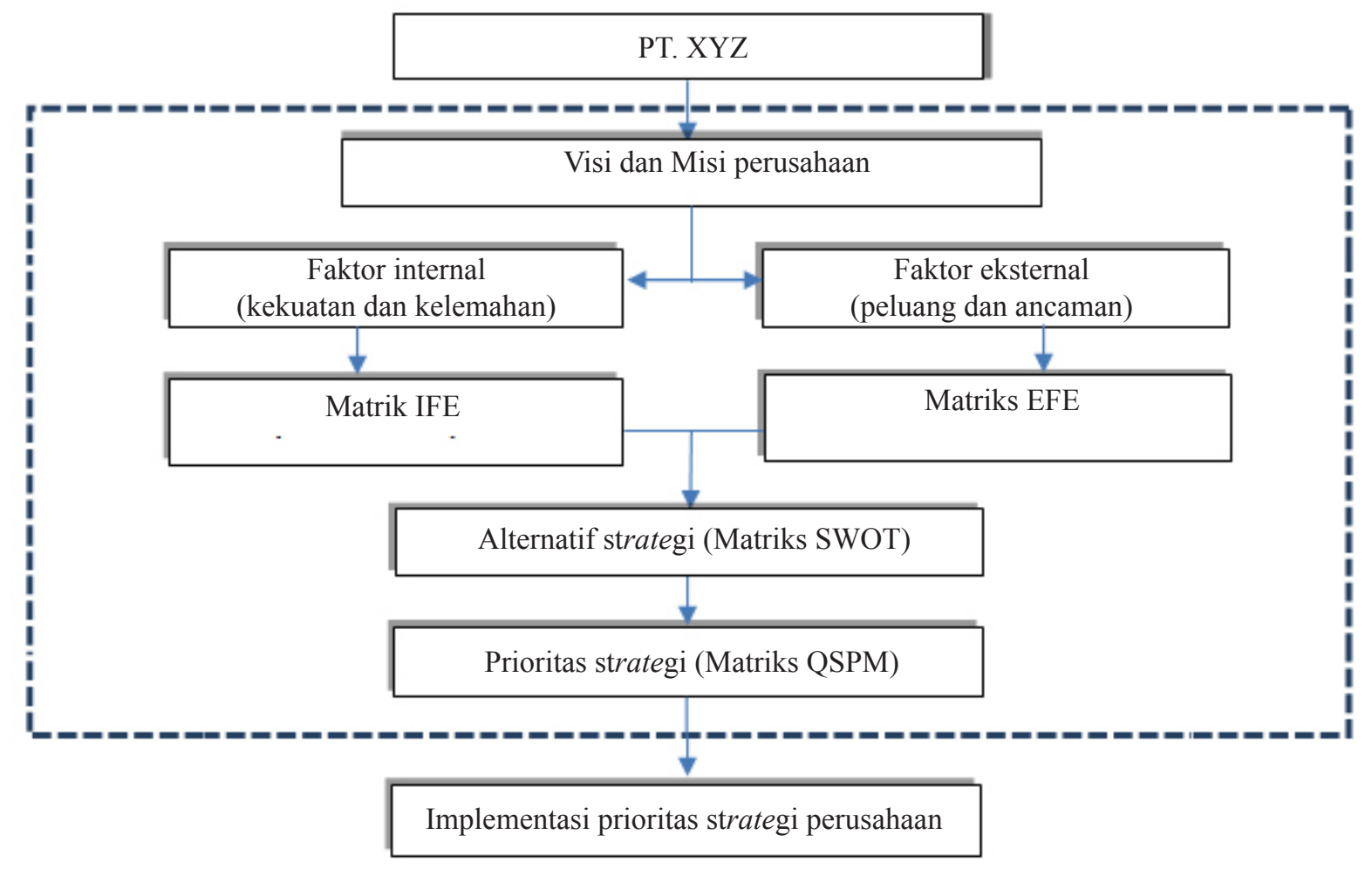

Gambar 1. Kerangka pemikiran penelitian 
Kelemahan utama PT.XYZ adalah perusahaan kurang agresif dalam mencari pelanggan baru, karena saat ini perusahaanya hanya berfokus pada satu cutomer saja dengan bobot 0,131 . Dengan hanya berfokus terhadap satu pelanggan saja perusahaan akan menjadi sangat tergantung dan tidak dapat mengembangkan armadanya secara maksimal. Kelemahan kedua adalah struktur organisasi yang belum tertata dengan baik dengan bobot 0,129 . Kelemahan ketiga adalah adanya jabatan rangkap yang dipegang oleh seorang manager dengan bobot 0,124 . dan kelemahan terakhir adalah kemampuan SDM yang dimiliki masih sangat terbatas dengan bobot 0,122 .

Menurut david (2006), jika dalam analisis IFE nilai skor yang didapat lebih dari 2,5. Artinya, perusahaan dapat menggunakan kekuatanya dan minimilkan kelemahan secara maksimal. Pada perusahaan PT. XYZ, berdasarkan hasil dari evaluasi faktor internal (IFE) yang dilakukan, nilai IFE total adalah 2,525. Artinya, perusahaan mampu menggunakan kekuatanya dengan baik dalam strategi perusahaan. Untuk hasil skor IFE secara lebih lengkap dapat dilihat dilihat Tabel 2

\section{Analisis Lingkungan Eksternal}

Hasil matriks EFE maka diperoleh peluang dan ancaman dalam perumusan strategi bisnis PT.XYZ.
Menurut david (2006), jika skor EFE yang didapatkan lebih dari 2,5. Artinya, perusahaan atau organisasi dalam menyikapi berbagai peluang dan ancaman, dilakukan dengan respon yang tinggi. Peluang utama dari perumusan strategi bisnis PT.XYZ adalah Indonesia secara geografis merupakan sebuah negara kepualauan dengan dua pertiga luas lautan lebih besar daripada daratan dengan bobot sebesar 0,137 . peluang kedua adalah pertumbuhan pasar yang diharapkan meningkat (prospek akan adanya peningkatan arus import dan eksport melalui transportasi laut) dengan bobot 0,130 . Peluang ketiga salah satu misi pemerintah adalah mengembangkan tol laut untuk pengembangan perkonomian negara dengan bobot 0,120 . Peluang keempat asas cabotage yang dikeluarkan pemerintah untuk mengembangkan perusahaan dalam negeri dengan bobot sebesar 0,119. Faktor ancaman terbesar dari perumusan strategi bisnis PT.XYZ adalah korupsi yang relatif tinggi dengan bobot sebesar 0,149. Faktor ancaman kedua Bertambahnya pesaing baru sebagai dampak dari kemudahan pengurusan perijinan angkutan laut (SIUPAL/SIOPSUS) dengan bobot sebesar 0,123 . Faktor ancaman yang ketiga nilai tukar rupiah fluktuatif dengan bobot sebesar 0,115. Faktor ancaman keempat Kemungkinan pergantian pemimpin negara dapat memengaruhi kebijakan dan strategi yang sudah berjalan dengan bobot sebesar 0,107 . Hasil skor EFE secara lebih lengkap dapat dilihat pada Tabel 3.

Tabel 2. Bobot dan rating evaluasi faktor internal

\begin{tabular}{|c|c|c|c|}
\hline Faktor internal & Bobot & Rating & Skor \\
\hline \multicolumn{4}{|l|}{ Kekuatan } \\
\hline Didukung oleh holding company yang besar & 0,153 & 4 & 0,613 \\
\hline $\begin{array}{l}\text { Memiliki perjanjian dengan shipper / pihak muatan untuk mengangkut muatan gandum } \\
\text { dalam jangka waktu yang tak terbatas }\end{array}$ & 0,144 & 4 & 0,575 \\
\hline Memiliki armada pengangkutan kapal curah yang sudah bersertifikasi Internasional & 0,109 & 3 & 0,325 \\
\hline $\begin{array}{l}\text { PT.XYZ menggunakan ISM code sebagai alat bantu untuk mencapai tingkat keselamatan } \\
\text { (safety) yang sesuai standard internasional sdalam mengoperasikan kapal }\end{array}$ & 0,093 & 4 & 0,333 \\
\hline Total skor kekuatan & & 1,846 & \\
\hline \multicolumn{4}{|l|}{ Kelemahan } \\
\hline Kemampuan SDM yang dimiliki masih sangat terbatas & 0,122 & 2 & 0,220 \\
\hline Adanya jabatan rangkap yang dipegang oleh seorang manajer & 0,124 & 1 & 0,174 \\
\hline Struktur organisasi masih belum tertata dengan baik & 0,129 & 1 & 0,155 \\
\hline $\begin{array}{l}\text { Perusahaan kurang agresif dalam mencari customer baru, karena saat ini perusahaan } \\
\text { hanya berfokus pada satu customer saja }\end{array}$ & 0,131 & 1 & 0,131 \\
\hline Total skor kelemahan & & 0,680 & \\
\hline Total skor faktor internal & & 2,526 & \\
\hline
\end{tabular}


Tabel 3. Bobot dan rating evaluasi faktor eksternal

\begin{tabular}{|c|c|c|c|}
\hline Faktor eksternal & Bobot & Rating & Skor \\
\hline \multicolumn{4}{|l|}{ Peluang } \\
\hline $\begin{array}{l}\text { Pertumbuhan pasar yang diharapkan meningkat (prospek akan adanya peningkatan arus } \\
\text { import dan eksport melalui transportasi laut) }\end{array}$ & 0,130 & 3 & 0,415 \\
\hline $\begin{array}{l}\text { Asas Cabotage yang dikeluarkan pemerintah untuk mengembangkan perusahaan dalam } \\
\text { negeri }\end{array}$ & 0,119 & 3 & 0,381 \\
\hline $\begin{array}{l}\text { Salah satu misi pemerintah adalah mengembangkan tol laut untuk pengembangan } \\
\text { perkonomian negara }\end{array}$ & 0,120 & 3 & 0,334 \\
\hline $\begin{array}{l}\text { Indonesia secara geografis merupakan sebuah negara kepulauan dengan dua pertiga luas } \\
\text { lautan lebih besar daripada daratan }\end{array}$ & 0,137 & 4 & 0,521 \\
\hline Total skor peluang & & 1,653 & \\
\hline \multicolumn{4}{|l|}{ Ancaman } \\
\hline $\begin{array}{l}\text { Kemungkinan pergantian pemimpin negara dapat memengaruhi kebijakan dan strategi yang } \\
\text { sudah berjalan }\end{array}$ & 0,107 & 3 & 0,320 \\
\hline Nilai tukar rupiah fluktuatif & 0,115 & 3 & 0,323 \\
\hline $\begin{array}{l}\text { Bertambahnya pesaing baru sebagai dampak dari kemudahan pengurusan perijinan } \\
\text { angkutan laut (SIUPAL/SIOPSUS) }\end{array}$ & 0,123 & 3 & 0,418 \\
\hline Korupsi yang masih relatif tinggi di Indonesia & 0,149 & 4 & 0,594 \\
\hline Total skor ancaman & & 1,657 & \\
\hline Total skor faktor eksternal & & 3,310 & \\
\hline
\end{tabular}

\section{Posisi Perusahaan dan Pilihan Strategi}

Matriks IFE dan EFE yang sudah mempunyai skor bobot yang telah lengkap disatukan dalam bentuk matriks IE untuk menunjukan posisi PT.XYZ dalam industri pelayaran. Dalam menentukan matriks IE dilakukan dengan melihat pada letak skor dalam kuadran kuadran dalam matriks internal dan eksternal. Berdasarkan dari nilai IFE dan EFE posisi PT.XYZ berada kuadran II dengan skor matriks IE (2,525; 3,310) (Tabel 4). Menurut David (2009) posisi pada kuadran menunjukkan bahwa strategi bisnis PT.XYZ berdasarkan faktor internal dan eksternal adalah melakukan strategi tumbuh dan kembangkan. Adapun beberapa strategi yang dapat dirumuskan berdasarkan posisi perusahaan adalah sebagai berikut:

Bekerja sama dengan pemerintah dalam menyiapkan armada khusus untuk pengangkutan dalam negeri sehingga mendukung industri pelayaran nasional

Pada saat ini pemerintah memberikan dukungan penuh dalam pengembangan indsutri pelayaran nasional itu tertuang dalam besarnya angaran yang akan dikeluarkan pemerintah dalam industri maritim nasional, berdasasrkan dari hasil IFE PT.XYZ mempunyai kemampuan finansial/modal yang sangat baik dari perusahaan induk tentunya menjadi peluang bagi PT.XYZ dalam mengembangkan bisnis perusahaanya dikarenakan dalam bisnis pelayaran diperlukan kemampuan finansial yang sangat baik. Disamping itu, PT.XYZ juga sudah mempunyai beberapa armada yang sudah bersertifikasi Internasional untuk pengangkutan muatan secara curah sehingga sangat memungkinkan bagi perusahaan untuk melakukan kerja sama dengan pemerintah dalam perkemabangan industri pelayaran nasional.

Melakukan kerja sama dengan beberapa pihak diluar perusahaan induk

Menurut Styhre (2009) Salah satu strategi yang tepat untuk meningkatkan utilisasi kapal laut dalam kondisi pasar yang berubah ubah adalah never say no strategy dimana strategi tersebut memanfaatkan peluang pasar yang ada semaksimalnya. Strategi dalam bekerja sama dengan pihak lain diluar perusahaan induk adalah merupakan salah satu strategi dalam mengatasi lamanya kapal idle di pelabuhan yang diakibatkan dari menurunya pembelian bahan mentah gandum dari perusahaan induk. Ketika terjadi kondisi stagnan atau kondisi kapal idle dalam waktu yang relatif lama maka perlu alternatif strategi dalam mengisi kekosongan tersebut. 


\begin{tabular}{|c|c|c|c|c|}
\hline \multirow{9}{*}{$\begin{array}{c}\text { Total Nilai EFE yang } \\
\text { Dibobot }\end{array}$} & & \multicolumn{3}{|c|}{ Total Nilai IFE yang Dibobot } \\
\hline & & Kuat & Rata-Rata & Lemah \\
\hline & & $3,0-4,0$ & $2,0-2,99$ & $1,0-1,99$ \\
\hline & Tinggi & I & 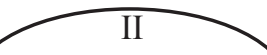 & III \\
\hline & $3,0-4,0$ & Grow \& Build & Grow \& Build & Hold \& Maintain \\
\hline & Sedang & IV & $\overline{\mathrm{V}}$ & VI \\
\hline & $2,0-2,99$ & Grow \& Build & Hold \& Maintain & Harvest or Divest \\
\hline & Rendah & VII & VIII & IX \\
\hline & $1,0-1,99$ & Hold \& Maintain & Harvest or Divest & Harvest or Divest \\
\hline
\end{tabular}

Peningkatan kapasitas SDM khususnya terhadap departemen komersial

Strategi peningkatan kapasitas SDM terhadap departemen komersial merupakan strategi yang sangat penting dalam perumusan strategi bisnis perusahaan kedepanya, dikarenakan peningkatan kapasitas karyawan berkorelasi positif terhadap daya saing perusahaan tersebut (Shammot, 2014). Pendidikan dan pelatihan dapat memengaruhi kinerja karyawan dalam mencapai tujuan dari perusahaan dalam menciptakan keunggulan kompetitif (Turere, 2013). Dalam persaingan bisnis perusahaan pelayaran perlu didukung oleh team team ahli yang menguasai tentang industri pelayaran sehingga dapat mengimplementasikan strategi tersebut kepada perusahaan dan menciptakan keunggulan kompetitif pada perusahaan. Salah satu faktor terjadinya kapal idle PT.XYZ adalah kurangnya pengetahuan dari departemen komersial dalam memperhitungkan dan menyampaikan kepada pihak top manajemen mengenai biaya yang timbul dari lamanya kapal idle tersebut dan faktor lain juga disebabkan oleh kurangnya pengetahuan dari departemen komersial dalam menyampaikan alternatif alternatif strategi yang memungkinkan dilakukan tanpa menggangu kepentingan dari perusahaan induk. Dalam strategi ini terdapat satu inisiatif yaitu pemberian pelatihan tentang bisnis dalam industri pelayaran seperti BL, LC, chartering, laytime calculation, insurance.

Bekerja sama dengan INSA dalam memberantas korupsi, kolusi dan nepotisme

Strategi kerja sama dengan INSA dalam memberantas korupsi, kolusi dan nepotisme merupakan strategi yang dilakukan untuk menekan tingkat korupsi dalam industri pelayaran di Indonesia. INSA merupakan wadah bagi seluruh pemilik kapal dan semua perusahaan pelayaran dalam menyampaikan aspirasi, saran, kritikan dan juga protes kepada pemerintah secara terstruktur. Salah satu kerja sama dengan INSA adalah tidak memberikan uang pungli atau biaya biaya yang tidak resmi di pelabuhan dan menerapakan GCG (Good Corporate Govermance) dimana menurut Kaihastsu (2006) GCG berperan dalam memberikan nilai tambah (value added) untuk semua stakeholder sehingga perusahaan dapat berkompetisi lebih fair dalam industri pelayaran.

Membangun mekanisme kerja yang baik sesuai dengan strutur organisasi sehingga dapat meningkatkan efisiensi kerja

Melalui strategi membangun mekanisme kerja yang tepat dan baik sesuai dengan struktur organisasi perusahaan dapat meningkatkan efesiensi kerja karyawan PT.XYZ. Dengan hal ini, diharapakan dapat memberikan kejelasan pada setiap karyawan terhadap tugas dan tanggung jawab masing masing karyawan. Dengan demikian, dalam operasional tidak terjadi kendala atau hambatan yang dapat menggangu strategi perusahaan kedepanya.

\section{Alternatif Strategi}

Penentuan alternatif strategi dalam mengkatkan daya saing perusahaan PT. XYZ dilakukan dengan menggunakan analisis SWOT, matriks SWOT (Gambar 2) menggunakan kekuatan organisasi untuk memanfatkan peluang dan mengatasi ancaman serta mengurangi kelemahan dengan peluang dan ancaman yang ada. Menurut David (2012) matriks SWOT adalah alat yang cocok digunakan untuk mencocokan faktor-faktor penting tersebut dengan menformulasikan beberapa tipe strategi, yaitu SO (StrengthOppurtunities), WO (Weaknesses-Oppurtunities), ST (Strength-Threats), dan WT (Weaknesses-Threats). 


\begin{tabular}{|c|c|c|}
\hline Faktor Eksternal & $\begin{array}{l}\text { Strength (S) } \\
\text { 1. Didukung oleh holding company yang } \\
\text { besar (S1) } \\
\text { 2. Memiliki perjanjian shipper/pihak muatan } \\
\text { (Bogasari) untuk mengangkut gandum } \\
\text { dalam jangka waktu yang tak terbatas (S2) } \\
\text { 3. Memiliki armadapengangkutan kapal } \\
\text { curah yang bersertifikasi Internasional } \\
\text { (S3) } \\
\text { 4. PT.SSM menggunakan sebagai alat bantu } \\
\text { untuk mencapai tingkat keselamatan } \\
\text { (safety) yang sesuai standard internasional } \\
\text { dalam mengoperasikan kapal (S4) }\end{array}$ & $\begin{array}{l}\text { Weaknesses (W) } \\
\text { 1. Kemampuan SDM yang dimiliki masih } \\
\text { sangat terbatas (W1) } \\
\text { 2. Adanya jabatan rangkap yang dipegang } \\
\text { oleh seorang manager (W2) } \\
\text { 3. Struktur organisasi masih belum tertata } \\
\text { dengan baik (W3) } \\
\text { 4. Perusahaan kurang agresif dalam mencari } \\
\text { customer baru, karena saat ini perusahaan } \\
\text { hanya berfokus pada satu customer saja } \\
\text { (W4) }\end{array}$ \\
\hline $\begin{array}{l}\text { Opportunities }(\mathrm{O}) \\
\text { 1. Pertumbuhan pasar yang diharapkan } \\
\text { meningkat (prospek akan adanya } \\
\text { peningkatan arus import dan eksport } \\
\text { melalui transportasi laut) (O1) } \\
\text { 2. Asas Cabotage yang dikeluarkan } \\
\text { pemerintah untuk mengembangkan } \\
\text { perusahaan dalam negeri (O2) } \\
\text { 3. Salah satu misi pemerintah adalah } \\
\text { mengembangkan tol laut untuk } \\
\text { pengembangan perkonomian negara } \\
\text { (O3) } \\
\text { 4. Indonesia secara geografis } \\
\text { merupakan sebuah negara kepulauan } \\
\text { dengan dua pertiga luas lautan lebih } \\
\text { besar daripada daratan (O4) }\end{array}$ & $\begin{array}{l}\text { Strategi S-O } \\
\text { 1. Bekerja sama dengan pemerintah dalam } \\
\text { menyiapkan armada khusus untuk } \\
\text { pengangkutan dalam negeri sehingga } \\
\text { mendukung industri pelayaran nasional } \\
\text { (S1,S3,S4,O2,O3,04) } \\
\text { 2. Membuat departemen khusus yang } \\
\text { mengatur tentang komersialisasi kapal } \\
\text { kapal SSM dalam industri pelayaran } \\
\text { 3. Mempromosikan keberhasilan kapal kapal } \\
\text { SSM dalam pengangkutan gandum dari } \\
\text { luar negeri (S2,S3,S4,O1,O2,O4) }\end{array}$ & $\begin{array}{l}\text { Strategi W-O } \\
\text { 1. Melakukan kerja sama dengan pihak lain } \\
\text { diluar Bogasari (W1,W2,W4,O1,O2,O4) } \\
\text { 2. Peningkatan kapasitas SDM khususnya } \\
\text { terhadap departmen komersial } \\
(\mathrm{W} 1, \mathrm{~W} 4, \mathrm{O} 1, \mathrm{O} 2)\end{array}$ \\
\hline $\begin{array}{l}\text { Threats }(\mathrm{T}) \\
\text { 1. Kemungkinan pergantian pemimpin } \\
\text { negara dapat memengaruhi } \\
\text { kebijakan dan strategi yang sudah } \\
\text { berjalan (T1) } \\
\text { 2. Nilai tukar rupiah fluktuatif (T2) } \\
\text { 3. Bertambahnya pesaing baru } \\
\text { sebagaidampak dari kemudahan } \\
\text { pengurusan perijinan angkutan laut } \\
\text { (SIUPAL/SIOPSUS) (T3) } \\
\text { 4. Korupsi yang masih relatif tinggi di } \\
\text { Indonesia (T4) }\end{array}$ & $\begin{array}{l}\text { Strategi S-T } \\
\text { 1. Bekerja sama dengan INSA dalam } \\
\text { memberantas korupsi, kolusi dan } \\
\text { nepotisme }(\mathrm{S} 1, \mathrm{~S} 3, \mathrm{~S} 4, \mathrm{~T} 3, \mathrm{~T} 4)\end{array}$ & $\begin{array}{l}\text { Strategi W-T } \\
\text { 1. Membangun mekanisme kerja yang } \\
\text { baik sesuai strutur organisasi dapat } \\
\text { meningkatkan kerja }(\mathrm{W} 1, \mathrm{~W} 2, \mathrm{~W} 3, \mathrm{~T} 3)\end{array}$ \\
\hline
\end{tabular}

Gambar 2. Hasil analisis matriks SWOT

\section{Prioritas Strategi}

Penentuan prioritas stratategi dilakukan dengan menggunakan metode QSPM. QSPM merupakan salah satu metode yang biasa dipakai dalam penentuan urutan prioritas strategi yang bertujuan mengevaluasi alternatif alternatif strategi yang paling memungkinkan untuk dijalankan terlebih dahulu. Dalam pemberian urutan prioritas strategi disini bukan berarti salah satu dari lima strategi tersebut tidak dijalankan, akan tetapi strategi tersebut dilaksanakan berdasarkan urutan prioritas. Melalui analisis QSPM, alternatif strategi yang didapatkan melalui analisis SWOT tersebut ditentukan urutan prioritasnya berdasarkan tingkat keterkaitan pada lingkungan internal dan external PT.XYZ sehingga alternatif strategi tersebut dapat dilakukan berdasarkan tingkatan prioritas kepentinganya. Hasil perhitungan dari QSPM dalam menentukan prioritas strategi bisnis PT.XYZ Selengkapnya pada Tabel 5.

Dalam pemberian urutan prioritas strategi disini bukan berarti salah satu dari lima alternatif strategi tersebut tidak dijalankan. Semua strategi ini dijalankan, akan tetapi pada saat menjalankan ada prioritas utama yang terlebih dahulu dijalankan. Prioritas utama dari lima alternatif strategi adalah. Peningkatan kapasitas 
SDM khususya terhadap department komersial dengan TAS sebesar 7,545. Pengembangan kapasitas SDM komersial merupakan salah satu faktor yang sangat perlu untuk dikembangkan terlebih dahulu dalam menjawab permasalahan yang timbul dari terjadinya kapal idle pada PT.XYZ. Faktor yang menyebabkan terjadinya kapal idle PT.XYZ disebabkan kurangnya pengetahuan dari komersial departemen dalam memperhitungkan dan menyampaikan biaya biaya yang timbul akibat dari lamanya kapal idle di pelabuhan dan juga disebabkan ketidakmampuan dari departemen komersial dalam memaparkan alternatif-alternatif strategi yang memungkinkan dilakukan dalam mengisi kekosongan kapal idle tanpa menggangu kepentingan dari perusahaan induk selaku pelanggan prioritas. Pengembangan kapasitas SDM terhadap karyawan komersial juga berimplikasi terhadap perencanaan strategik perusahaan kedepan.

Prioritas strategi yang kedua adalah PT. XYZ bekerja sama dengan INSA untuk tidak memberikan uang pungli kepada pejabat-pejabat yang berwenang, dengan bentuk kerja sama yang intens pada setiap instansi instansi yang berhubungan untuk tidak memberikan gratifikasi atau pungli dalam bentuk uang atau apapun kepada setiap pejabat yang berwenang dipelabuhan akan menciptakan kondisi dan image yang baik kepada setiap investor yang akan datang untuk masuk dalam industri pelayaran nasional sehingga industri pelayaran nasional dan PT.XYZ akan dapat lebih berkembang kedepanya. Prioritas ketiga adalah Melakukan kerja sama dengan pemerintah berupa pembelian armada kapal laut yang sesuai dengan rencana strategi pemerintah kedepanya atau dengan menyiapkan armada khusus untuk pengangkutan dalam negeri. Prioritas yang keempat adalah mengimplementasikan secara tepat dan benar struktur organisasi yang sudah dibuat agar karyawan dapat bekerja secara optimal. Menjalin kerja sama/contract dengan customer baru diluar dari perusahaan induk merupakan urutan prioritas kelima.

\section{Implikasi Manajerial}

Dalam hasil penelitian ini diharapakan dapat memberikan manfaat kepada perusahaan dalam hal ini departemen yang terkait dalam mengatasi permasalahan kapal idle yang terjadi pada PT.XYZ, dan juga pihak lain antara lain: 1) bagi departemen komersial, dalam penelitian tersebut dipaparkan beberapa alternatif alternatif strategi yang dapat dilaksanakan dalam mengatasi kapal idle; 2) bagi departemen HRD, dalam penelitian dipaparkan tentang pentingnya peningkatan kapasitas setiap karyawan secara berkala dalam meningkatkan daya saing perusahaan, dalam penelitian tersbut juga dipaparkan pentingya mekanisma kerja yang terstruktur dan baik antar departemen sehingga menciptakan sinergitas pada setiap departemen; 3) bagi departemen operation, dalam penelitian dipaparkan tentang menjalin kerja sama yang baik kepada beberapa instansi untuk mencipatakan peluang bisnis baru dan juga mendorong pemerintah agar menghilangkan praktik-praktik pungli yang dapat membebani perusahaan PT.XYZ dan perusahaan lainya; 4) bagi perusahaan sejenis penilitian dapat dijadikan literatur dalam menentukan strategi yang tepat pada perusahaanya

Tabel 5. Hasil Perhitungan QSPM

\begin{tabular}{lcc}
\hline \multicolumn{1}{c}{ Strategi alternatif } & TAS & Urutan prioritas \\
\hline $\begin{array}{l}\text { Bekerja sama dengan pemerintah dalam menyiapkan armada khusus untuk } \\
\text { pengangkutan dalam negeri sehingga mendukung industri pelayaran nasional }\end{array}$ & 7,248 \\
Bekerja sama dengan pihak lain diluar perusahaan induk & 7,223 & 3 \\
Peningkatan kapasitas SDM khususnya terhadap departemen komersial & 7,545 & 1 \\
Bekerja sama dengan INSA dalam memberantas korupsi, kolusi dan nepotisme & 7,343 & 2 \\
Membangun mekanisme kerja yang baik sesuai dengan strutur organisasi sehingga & 7,240 & 4 \\
dapat meningkatkan efisiensi kerja & & 5 \\
\hline
\end{tabular}




\section{KESIMPULAN DAN SARAN}

\section{Kesimpulan}

Hasil analisis internal (IFE) dapat terlihat bahwa faktor internal yang berperan sebagai kekuatan utama dalam PT.XYZ adalah didukung oleh perusahaan induk yang besar. Sedangkan kelemahan utama dari PT.XYZ adalah perusahaan kurang agresif dalam mencari pelanggan baru, karena saat ini perusahaanya hanya berfokus pada satu pelanggan saja. Selanjutnya, Hasil analisis external (EFE) yang dilaksanakan, dapat terlihat bahwa peluang utama yang dimiliki oleh PT.XYZ adalah Indonesia merupakan sebuah negara kepulauan dengan dua pertiga luas lautan lebih besar daripada daratan. Ancaman utama pada PT.XYZ adalah tingkat korupsi yang relatif masih tinggi di Indonesia. Berdasarkan dari hasil analisis IFE dan EFE posisi perusahaan PT.XYZ berada dalam kuadran II. Posisi tersebut menunjukan strategi perusahaan PT.XYZ dalam perumusan strategi bisnis adalah melakukan strategi tumbuh dan kembangkan baik itu berupa peneterasi pasar baru, pengembangan strategi bisnis perusahaan, pengembangan produk atau integrasi kedepan atau kebelakang

Dalam mendapatkan alternatif strategi dilakukan analisis SWOT, dimana dalam analisis SWOT tersebut didapatkan lima alternatif strategi yang bisa dilakukan pada PT.XYZ dalam perumusan strategi bisnis perusahan, yaitu 1) bekerja sama dengan pemerintah dalam menyiapkan armada khusus untuk pengangkutan dalam negeri sehingga mendukung industri pelayaran nasional; 2) menjalin kerja sama/contract dengan beberapa pihak diluar dari perusahaan induk; 3) meningkatan kapasitas SDM khususnya terhadap departemen komersial; 4) bekerja sama dengan INSA dalam memberantas korupsi, kolusi dan nepotisme; 5) membangun mekanisme kerja yang baik sesuai dengan strutur organisasi sehingga dapat meningkatkan efisiensi kerja. Adapun, prioritas strategi utama adalah peningkatan kapasitas SDM khususnya terhadap departemen komersial dengan TAS sebesar 7,545.

\section{Saran}

PT.XYZ adalah perusahaan pelayaran nasional yang mempunyai potensi dikembangkan menjadi perusahaan pelayaran nasional yang sukses. Akan tetapi, perkembangan industri pelayaran nasional dan luar negeri sering sekali mengalami perubahan yang cepat dan persaingan pasar yang sangat ketat. Dengan demikian, membutuhkan perhatian dan komitmen penuh dari semua manajemen perusahaan baik itu management PT.XYZ, tetapi juga oleh manajemen perusahaan induk untuk setiap perencanaan strategi yang sudah dirancang. Perusahaan harus senantiasa menganalisis sumber sumber kemampuan perusahaan secara berkelanjutan agar dapat terus bersaing dengan perusahaan lain dan dapat menciptakan alternatif alternatif strategi yang lebih baru yang dapat dikembangkan (Adams dan Lamont, 2003). Perlu adanya penelitian mendalam pada setiap segmen industri bisnis pelayaran yang akan dimasuki oleh PT.XYZ dikarenakan adanya perbedaan kebutuhan dan regulasi dari pemilik muatan (shipper) atau penyewa kapal (charterer) untuk kapal kapal yang akan digunakan (Plomfaritou et al. 2011).

\section{DAFTAR PUSTAKA}

Adams GL, Lamont BT. 2003. Knowlege management systems and developing sustainable competitive advantage. Journal of Knowledge Management. 7(2): 142-154. https://doi. org/10.1108/13673270310477342.

Badan Pusat Statistik. 2014. Perkembangan ekspor dan impor indonesia maret 2014. http://www.bps. go.id/brs_file/eksim_02mei14.pdf. [12 Februari 2014].

Cifci S, Kocak A. 2012. The impact of brand positivity on the relationship between corporate image and consumers' attitudes toward brand extension in service businesses. Corporate Reputation Review 15(2): 105-118. https://doi.org/10.1057/ crr.2012.5.

David FR. 2006. Manajemen Strategis: Konsep-konsep. Ichsan Setiyo, penerjemah, Jakarta: Salemba Empat.

Gao Z, Yoshida S. 2013. Analysis on industrial structure and competitive strategies in liner shipping industry. Journal of Management and Strategy 4(4): 12-20. .https://doi.org/10.5430/ jms.v4n4p12.

Hernowo P. 2000. Perumusan strategi bisnis PT. Karana Line [disertasi]. Bogor: Sekolah Program Pascasarjana, Institut Psertanian Bogor.

Kaufman JL, Jacobs HM. 1996. A public planning perspective on strategic planning. Journal of the American Planning Association. 1(53):1-32.

Komaryatin N. 2007. Strategi pemasaran dengan pendekatan SWOT. Jurnal Dinamika Ekonomi 
dan Bisnis 4(1): 85-100.

Kurniawati T, Sari KBDK. 2009. Analisis dan pilihan Strategi: membangun eksistensi perusahaan di masa kritis. Journal Ekonomi Bisnis 14(3): 179190.

Lagoudis IN, Lalwani CS, Naim MM. 2004. A generic systems model for ocean shipping companies in the bulk sector. Transportation Journal 43(1)5: 56.

Powel TC. 2004. Strategy, execution and idle rationality. Journal of Management Research 48(4): 30-39.

Sheehan NT. 2012. A risk-based approach to strategy execution. Journal of Business Strategy 29(3): 25-34.
Styhre L. 2009. Strategies for capacity utilisation in short sea shipping. Journal of Maritime Economics \& Logistic 11(4): 418-437. https:// doi.org/10.1057/mel.2009.11.

Turere VN. 2013. Pengaruh pendidikan dan pelatihan terhadap peningkatan kinerja karyawan pada Balai Pelatihan Teknis Pertanian Kalasey. Jurnal Riset Ekonomi, Manajemen, Bisinis dan Akutansi 1(3): 10-19.

Xia Chan. 2011. A SWOT study of the development strategy of haier group as one of the most successful chinese enterprises. International Jurnal of Business and Social Science 2(11): 147-153. 